\title{
MULTI - OBJECTIVE OPTIMIZATION OF MACHINING PARAMETERS OF EN36 STEEL USING RSM
}

\author{
M. Murali Mohan ${ }^{1}$, N.V.S.S. Sagar², M. Lava Kumar ${ }^{3}$, E. Venugopal Goud ${ }^{4}$ \\ ${ }^{1}$ Assistant Professor, Department of Mechanical Engineering, G. Pulla Reddy Engg, College, Kurnool, A.P, India \\ ${ }^{2}$ Assistant Professor, Department of Mechanical Engineering, G. Pulla Reddy Engg, College, Kurnool, A.P, India \\ ${ }^{3}$ Assistant Professor, Department of Mechanical Engineering, G. Pulla Reddy Engg, College, Kurnool, A.P, India \\ ${ }^{4}$ Associate Professor, Department of Mechanical Engineering, G. Pulla Reddy Engg, College, Kurnool, A.P, India
}

\begin{abstract}
This paper reports on the optimization of turning process on all geared lathe by the effects of machining parameters applying Response Surface Methodology (RSM) to improve the quality of manufactured goods, and engineering development of designs for studying variations. EN36 is used as the work piece material and TNMG insert is used as a tool for carrying out the experimentation to optimize the Temperature, and Surface Roughness. There are three machining parameters i.e. Spindle speed, Feed rate, Depth of cut. Twenty Seven experiments are done by varying all the parameters. Regression equations are generated from RSM. Their functional relationship and effect on different parameters is studied. ANOVA is applied to know which input parameter has most significant effect on temperature and surface roughness. It is observed that as the spindle speed and depth of cut decreases the temperature decreases. The surface roughness is minimum when the spindle speed is high and feed is less. Optimum value of each parameter will be obtained by using Minitabl6 Software.
\end{abstract}

Keywords: EN 36, RSM, TNMG, Surface roughness, ANOVA.

\section{INTRODUCTION}

All machining processes remove material to form shapes. As metals are still the most widely used materials in manufacturing, machining processes are usually used for metals. However, machining can also be used to shape plastics and other materials which are becoming more widespread. Basically all the different forms of machining involve removing material from a component using a rotating cutter. The differences between the various types arise from the relative motion between cutting tool and work piece and the type of cutting tool used. Typically machining will be done using a machine tool. This tool holds the work piece and the rotating cutting tool and allows relative movement between the two. Usually machine tools are dedicated to one type of machining operation, although some more flexible tools allow more than one type of machining to be performed.

The machine tool can either be under manual or automatic control. Automatic control is more expensive because of the need to invest in the necessary control mechanisms however it becomes more desirable as the number of components produced increases and labour costs can be reduced. The speed at which a machine tool can process individual components is a function of the cutting speed of the tool and the downtime involved in changing the work piece and maintaining the tool (this will usually involve changing the cutting edges of the tool). Some very flexible tools allow automatic changing of components and cutting tools, however they greatly add to initial purchase price of the machine tool. The cutting speed of the tool is usually dictated by the type of material being machined, in general the harder the material, the slower the machining time. Machining speed can be increased by increasing the rotational speed of the cutter; however this will be at the expense of the tool life. Hence for machining processes there is an optimum cutting speed that balances tooling costs with cutting speed.

It is important to view machining, as well as all manufacturing operations, as a system consisting of the work piece, the tool and the machine.

\subsection{Nomenclatures}

\begin{tabular}{|l|l|}
\hline D & Depth of cut \\
\hline F & Feed \\
\hline S & Speed \\
\hline T & Temperature \\
\hline SR & Surface Roughness \\
\hline
\end{tabular}

\section{EXPERIMENTAL SETUP}

\subsection{Workpiece Material}

EN36 steel is used as the work piece material for carrying out the experimentation to optimization of cutting parameters. The bars used are of diameter $25 \mathrm{~mm}$ and length $100 \mathrm{~mm}$. The turning process is done over a length of $50 \mathrm{~mm}$. The chemical composition and mechanical properties of EN36 is shown in table 2.1 and 2.2. 
Table 2.1: Chemical Composition

\begin{tabular}{|l|l|l|}
\hline S.NO & METAL & $\begin{array}{l}\text { COMPOSITION BY } \\
\text { WEIGHT IN (\%) }\end{array}$ \\
\hline 1 & Carbon & 0.14 \\
\hline 2 & Silicon & 0.19 \\
\hline 3 & Manganese & 0.46 \\
\hline 4 & Sulphur & 0.009 \\
\hline 5 & Phosphorous & 0.006 \\
\hline 6 & Nickel & 3.55 \\
\hline 7 & Chromium & 1.11 \\
\hline 8 & Molybdenum & 0.12 \\
\hline
\end{tabular}

Table 2.2: Mechanical Properties

\begin{tabular}{|l|l|l|l|l|l|}
\hline $\begin{array}{l}\text { Sect } \\
\text { ion } \\
\text { mm }\end{array}$ & $\begin{array}{l}\text { Yield } \\
\text { Strengt } \\
\text { h } \\
\text { Mpa }\end{array}$ & $\begin{array}{l}\text { Tensile } \\
\text { Strength } \\
\text { Mpa }\end{array}$ & $\begin{array}{l}\text { Elong } \\
\text { ation } \\
(\%)\end{array}$ & $\begin{array}{l}\text { Impact } \\
\text { izod } \\
\text { J }\end{array}$ & $\begin{array}{l}\text { Hard } \\
\text { ness } \\
\text { HB }\end{array}$ \\
\hline 25 & 950 & 1150 & 15 & 45 & 340 \\
\hline
\end{tabular}

Typical applications: EN36 steel has wide applications. It is used in disc wheels, grooved shaft, cams, gears, and heavy duty gears for air craft's, heavy vehicles, universal joints and auto mobile transmission parts.

\subsection{All Geared Lathe}

These machines are known for their sturdy construction, high performance and noiseless operation. The following are the specifications of the lathe. This table will give the ranges of the speed, feed, and depth of cut of the lathe machine that are possible to set.
Swing over the bed
$=310 \mathrm{~mm}$
Length of bed

$$
=1530 \mathrm{~mm}
$$$$
=18
$$

Table 2.3: Feeds available

\begin{tabular}{|l|l|l|l|l|l|l|l|l|}
\hline & \multicolumn{3}{l}{ SII } & \multicolumn{2}{l|}{ SI } & \multicolumn{2}{l|}{ SII } & \multicolumn{2}{l|}{ SI } \\
\hline & L & H & L & H & L & H & L & H \\
\hline E & 1.29 & 0.27 & 0.64 & 0.31 & 0.32 & 0.06 & 0.16 & 0.03 \\
2 & 1 & 6 & 6 & 8 & 3 & 9 & 1 & 4 \\
\hline E & 1.14 & 0.24 & 0.57 & 0.13 & 0.28 & 0.06 & 0.14 & 0.03 \\
3 & 7 & 5 & 4 & 2 & 7 & 1 & 3 & 1 \\
\hline A & 1.03 & 0.22 & 0.51 & 0.11 & 0.25 & 0.05 & 0.12 & 0.02 \\
2 & 3 & 1 & 6 & & 8 & 5 & 9 & 7 \\
\hline E & 0.92 & 0.19 & 0.46 & 0.09 & 0.23 & 0.04 & 0.11 & 0.02 \\
4 & 2 & 7 & 1 & 9 & 1 & 9 & 5 & 5 \\
\hline E & 0.82 & 0.18 & 0.41 & 0.09 & 0.20 & 0.04 & 0.10 & 0.02 \\
1 & 1 & 4 & & 2 & 5 & 6 & 3 & 3 \\
\hline C & 0.73 & 0.15 & 0.36 & 0.07 & 0.18 & 0.03 & 0.09 & \\
3 & 8 & 7 & 9 & 9 & 4 & 9 & 2 & 0.02 \\
\hline C & 0.66 & 0.14 & 0.33 & 0.07 & 0.16 & 0.03 & 0.08 & 0.01 \\
4 & 4 & 2 & 2 & 1 & 6 & 6 & 3 & 8 \\
\hline A & 0.63 & 0.13 & 0.31 & 0.06 & 0.51 & 0.03 & 0.07 & 0.01 \\
5 & 3 & 5 & 6 & 8 & 8 & 4 & & 7 \\
\hline D & 0.52 & 0.11 & 0.26 & 0.05 & 0.13 & 0.02 & 0.06 & 0.01 \\
5 & 7 & 3 & 4 & 6 & 2 & 8 & 6 & 4 \\
\hline B & 0.42 & 0.09 & 0.21 & 0.04 & 0.10 & 0.02 & 0.05 & 0.01 \\
5 & 2 & 1 & 5 & 5 & 2 & 3 & 1 \\
\hline
\end{tabular}

In the above table,

$\mathrm{L}=$ longitudinal feed and

$\mathrm{H}=$ horizontal feed.

The values of first four lines are the feed that are possible with the gear combination 48-127-24. The remaining four lines are the feed that are possible with the gear combination 24-120-48.

Table 2.4: Speeds available

\begin{tabular}{|l|l|l|l|l|}
\hline \multicolumn{2}{|c|}{} & 1 & 2 & 3 \\
\hline \multirow{4}{*}{ I } & A & 360 & 1810 & 1095 \\
\cline { 2 - 5 } & B & 100 & 500 & 300 \\
\cline { 2 - 6 } & C & 280 & 1400 & 840 \\
\hline \multirow{5}{*}{} & & 1 & 2 & 3 \\
\hline \multirow{5}{*}{ II } & A & 235 & 1200 & 700 \\
\cline { 3 - 6 } & B & 65 & 330 & 200 \\
\cline { 3 - 6 } & C & 160 & 910 & 550 \\
\hline
\end{tabular}

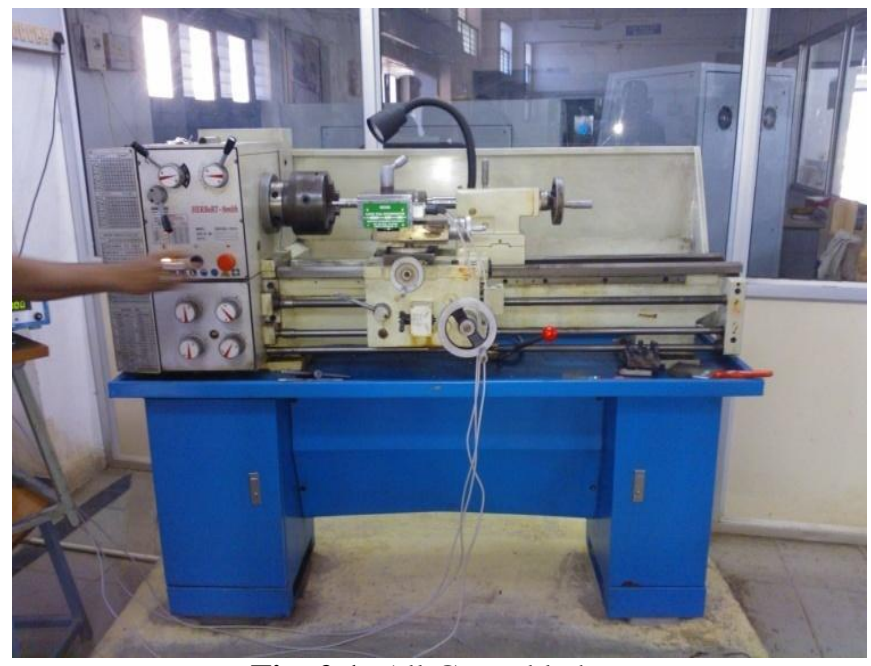

Fig. 2.1: All Geared lathe

\subsection{Cutting Tool Used}

The tool is single point cutting tool made of Tungsten Carbide. This insert is triangle shaped with three cutting edges on either side.

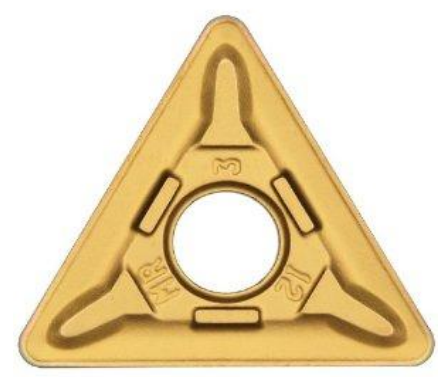

Fig. 2.2: TNMG Insert 


\subsection{Experimental Design with Three Level Factors}

The nonlinear relationship among the process parameters, if it exists, can only be revealed if more than two levels of the parameters are considered. Thus each selected parameter was analyzed at three levels. The process parameters and their values at three levels are given in table 2.5.

Table 2.5: Parameter levels

\begin{tabular}{|l|l|l|l|}
\hline Levels & $\begin{array}{l}\text { Depth of cut } \\
(\mathbf{m m})\end{array}$ & $\begin{array}{l}\text { Feed rate } \\
(\mathbf{m m} / \mathbf{r e v})\end{array}$ & $\begin{array}{l}\text { Spindle speed } \\
(\mathbf{r p m})\end{array}$ \\
\hline 1 & 0.3 & 0.105 & 400 \\
\hline 2 & 0.6 & 0.158 & 800 \\
\hline 3 & 0.9 & 0.205 & 1200 \\
\hline
\end{tabular}

\subsection{Historical Data}

The historical values of depth of cut, feed, speed, temperature and surface roughness are shown in table 2.6.

Table 2.6: Historical data in measuring Temperature and Surface Roughness

\begin{tabular}{|l|l|l|l|l|l|}
\hline $\begin{array}{l}\text { S.N } \\
\text { o. }\end{array}$ & $\begin{array}{l}\text { Dept } \\
\text { h of } \\
\text { cut } \\
(\mathbf{m m} \\
\mathbf{)}\end{array}$ & $\begin{array}{l}\text { Feed } \\
\text { rate } \\
(\mathbf{m m} / \mathbf{R e} \\
\mathbf{v})\end{array}$ & $\begin{array}{l}\text { Spind } \\
\text { le } \\
\text { Speed } \\
(\mathbf{r p m})\end{array}$ & $\begin{array}{l}\text { Tempe } \\
\text { rature( } \\
\text { C) }\end{array}$ & $\begin{array}{l}\text { Surface } \\
\text { Roughne } \\
\text { Ss } \\
(\boldsymbol{\mu m})\end{array}$ \\
\hline 1 & 0.3 & 0.105 & 400 & 32.35 & 7.66 \\
\hline 2 & 0.3 & 0.105 & 800 & 35 & 7.93 \\
\hline 3 & 0.3 & 0.105 & 1200 & 33.5 & 7.33 \\
\hline 4 & 0.3 & 0.158 & 400 & 35.5 & 15.18 \\
\hline 5 & 0.3 & 0.158 & 800 & 34 & 15.09 \\
\hline 6 & 0.3 & 0.158 & 1200 & 32.5 & 16.02 \\
\hline 7 & 0.3 & 0.205 & 400 & 33.5 & 31.53 \\
\hline 8 & 0.3 & 0.205 & 800 & 35.35 & 30.44 \\
\hline 9 & 0.3 & 0.205 & 1200 & 32.75 & 30.21 \\
\hline 10 & 0.6 & 0.105 & 400 & 36.25 & 8.98 \\
\hline 11 & 0.6 & 0.105 & 800 & 34.5 & 7.72 \\
\hline 12 & 0.6 & 0.105 & 1200 & 45 & 7.58 \\
\hline 13 & 0.6 & 0.158 & 400 & 38.25 & 17.30 \\
\hline 14 & 0.6 & 0.158 & 800 & 36.5 & 16.26 \\
\hline 15 & 0.6 & 0.158 & 1200 & 33.75 & 17.81 \\
\hline 16 & 0.6 & 0.205 & 400 & 36.05 & 31.22 \\
\hline 17 & 0.6 & 0.205 & 800 & 37.35 & 32.29 \\
\hline 18 & 0.6 & 0.205 & 1200 & 36.5 & 31.64 \\
\hline 19 & 0.9 & 0.105 & 400 & 35.75 & 10.51 \\
\hline 20 & 0.9 & 0.105 & 800 & 35.25 & 8.85 \\
\hline 21 & 0.9 & 0.105 & 1200 & 39 & 12.05 \\
\hline 22 & 0.9 & 0.158 & 400 & 35.5 & 15.53 \\
\hline 23 & 0.9 & 0.158 & 800 & 44.5 & 16.17 \\
\hline 24 & 0.9 & 0.158 & 1200 & 37.5 & 16.94 \\
\hline 25 & 0.9 & 0.205 & 400 & 35.5 & 31.17 \\
\hline 26 & 0.9 & 0.205 & 800 & 39 & 30.76 \\
\hline 27 & 0.9 & 0.205 & 1200 & 34.75 & 32.12 \\
\hline & & & & & \\
\hline & & & \\
\hline
\end{tabular}

\section{RESULTS}

The analysis is made using the Minitab 16 software. The effect of feed, spindle speed and depth of cut and there interaction on the temperature and surface quality (roughness) has been developed using multiple regression model. The analysis of variance (ANOVA) was applied to study the effect of the input parameters on the surface roughness and temperature.

Table 3.1 gives the Estimated Regression Coefficients of temperature for uncoded units. The value " $p$ " for the model is less than 0.05 which indicates that the model terms are significant, which is desirable as it indicates that the terms in the model have a significant effect on the response.

Table 3.1: Estimated Regression Coefficients for $T$

\begin{tabular}{|l|l|l|l|l|}
\hline Term & Coef & SE Coef & $\mathrm{T}$ & $\mathrm{P}$ \\
\hline Constant & 10.531 & 0.8571 & 12.287 & 0.000 \\
\hline $\mathrm{D}$ & 4.587 & 1.1061 & 4.147 & 0.001 \\
\hline $\mathrm{F}$ & 200.549 & 9.0198 & 22.234 & 0.000 \\
\hline $\mathrm{S}$ & 0.012 & 0.0008 & 14.270 & 0.000 \\
\hline $\mathrm{D} \times \mathrm{D}$ & -0.617 & 0.7656 & -0.806 & 0.431 \\
\hline $\mathrm{F} \times \mathrm{F}$ & -611.089 & 27.6762 & -22.080 & 0.000 \\
\hline $\mathrm{S} \times \mathrm{S}$ & -0.000 & 0.0000 & -0.806 & 0.431 \\
\hline $\mathrm{D} \times \mathrm{F}$ & -5.660 & 3.2460 & -1.744 & 0.099 \\
\hline $\mathrm{D} \times \mathrm{S}$ & 0.001 & 0.0004 & 1.710 & 0.105 \\
\hline $\mathrm{F} \times \mathrm{S}$ & 0.004 & 0.0024 & 1.744 & 0.099 \\
\hline
\end{tabular}

$\mathrm{S}=0.168770 \quad$ PRESS $=1.65827$

$\mathrm{R}-\mathrm{Sq}=99.90 \% \mathrm{R}-\mathrm{Sq}(\mathrm{pred})=99.66 \%$

$\mathrm{R}-\mathrm{Sq}(\operatorname{adj})=99.85 \%$

The regression equations generated for temperature is as follows

$$
\begin{gathered}
T=10.531+4.587 \times \mathrm{D}+200.549 \times \mathrm{F}+0.012 \times \mathrm{S}-0.617 \times \\
\mathrm{D}^{2}-611.089 \times \mathrm{F}^{2}-5.66 \times \mathrm{D} \times \mathrm{F}+0.001 \times \mathrm{D} \times \mathrm{S}+0.004 \times \\
\mathrm{F} \times \mathrm{S}
\end{gathered}
$$

From Response surface Eq. (3.1), the most significant factor on the temperature is speed. The next contribution on temperature is depth of cut and feed. The ANOVA for temperature is shown in table 3.2

Table 3.2: Analysis of Variance for $T$

\begin{tabular}{|l|l|l|l|l|l|l|}
\hline Source & $\begin{array}{l}\text { D } \\
\text { F }\end{array}$ & Seq SS & $\begin{array}{l}\text { Adj } \\
\text { SS }\end{array}$ & $\begin{array}{l}\text { Adj } \\
\text { MS }\end{array}$ & F & P \\
\hline $\begin{array}{l}\text { Regres } \\
\text { sion }\end{array}$ & 9 & $\begin{array}{l}480.47 \\
9\end{array}$ & $\begin{array}{l}480.4 \\
79\end{array}$ & $\begin{array}{l}53.386 \\
5\end{array}$ & $\begin{array}{l}1874 . \\
31\end{array}$ & 0.000 \\
\hline Linear & 3 & $\begin{array}{l}466.29 \\
9\end{array}$ & $\begin{array}{l}18.30 \\
3\end{array}$ & 6.1009 & $\begin{array}{l}214.1 \\
9\end{array}$ & 0.000 \\
\hline D & 1 & 20.056 & 0.490 & 0.4898 & 17.20 & 0.001 \\
\hline F & 1 & 6.188 & $\begin{array}{l}14.08 \\
1\end{array}$ & $\begin{array}{l}14.081 \\
1\end{array}$ & $\begin{array}{l}494.3 \\
6\end{array}$ & 0.000 \\
\hline S & 1 & $\begin{array}{l}440.05 \\
6\end{array}$ & $\begin{array}{l}5.800 \\
5.7999\end{array}$ & $\begin{array}{l}203.6 \\
3\end{array}$ & 0.000 \\
\hline Square & 3 & 13.923 & $\begin{array}{l}13.29 \\
3\end{array}$ & 4.6411 & $\begin{array}{l}162.9 \\
4\end{array}$ & 0.000 \\
\hline D×D & 1 & 0.019 & 0.019 & 0.0185 & 0.65 & 0.431 \\
\hline
\end{tabular}




\begin{tabular}{|c|c|c|c|c|c|c|}
\hline $\mathrm{F} \times \mathrm{F}$ & 1 & 13.886 & $\begin{array}{l}13.88 \\
6\end{array}$ & $\begin{array}{l}13.886 \\
3\end{array}$ & $\begin{array}{l}487.5 \\
3\end{array}$ & 0.000 \\
\hline $\mathrm{S} \times \mathrm{S}$ & 1 & 0.019 & 0.019 & 0.0185 & 0.65 & 0.431 \\
\hline $\begin{array}{l}\text { Interac } \\
\text { tion }\end{array}$ & 3 & 0.257 & 0.257 & 0.0855 & 3.00 & 0.059 \\
\hline $\mathrm{D} \times \mathrm{F}$ & 1 & 0.087 & 0.087 & 0.0866 & 3.04 & 0.099 \\
\hline $\mathrm{D} \times \mathrm{S}$ & 1 & 0.083 & 0.083 & 0.0833 & 2.93 & 0.105 \\
\hline $\mathrm{F} \times \mathrm{S}$ & 1 & 0.087 & 0.087 & 0.0866 & 3.04 & 0.099 \\
\hline $\begin{array}{l}\text { Residu } \\
\text { al } \\
\text { Error }\end{array}$ & $\begin{array}{l}1 \\
7\end{array}$ & 0.484 & 0.484 & 0.0285 & & \\
\hline Total & $\begin{array}{l}2 \\
6\end{array}$ & $\begin{array}{l}480.96 \\
3\end{array}$ & & & & \\
\hline
\end{tabular}

Table 3.3 gives the Estimated Regression Coefficients of surface roughness for uncoded units. The value " $p$ " for the model is less than 0.05 which indicates that the model terms are significant, which is desirable as it indicates that the terms in the model have a significant effect on the response.

Table 3.3: Estimated Regression Coefficients for SR

\begin{tabular}{|l|l|l|l|l|}
\hline Term & Coef & SE Coef & T & P \\
\hline Constant & 19.31 & 3.0881 & 6.253 & 0.000 \\
\hline $\mathrm{D}$ & 11.92 & 3.9850 & 2.991 & 0.008 \\
\hline $\mathrm{F}$ & -300.88 & 32.4962 & -9.259 & 0.000 \\
\hline $\mathrm{S}$ & -0.01 & 0.0030 & -1.855 & 0.081 \\
\hline $\mathrm{D} \times \mathrm{D}$ & -7.43 & 2.7581 & -2.692 & 0.015 \\
\hline $\mathrm{F} \times \mathrm{F}$ & 1755.23 & 99.7107 & 17.603 & 0.000 \\
\hline $\mathrm{S} \times \mathrm{S}$ & 0.00 & 0.0000 & 1.981 & 0.064 \\
\hline $\mathrm{D} \times \mathrm{F}$ & -22.76 & 11.6947 & -1.946 & 0.068 \\
\hline $\mathrm{D} \times \mathrm{S}$ & 0.00 & 0.0015 & 2.065 & 0.054 \\
\hline $\mathrm{F} \times \mathrm{S}$ & -0.00 & 0.0088 & -0.466 & 0.647 \\
\hline
\end{tabular}

$\mathrm{S}=0.608038 \quad$ PRESS $=15.1617$

$\mathrm{R}-\mathrm{Sq}=99.74 \% \mathrm{R}-\mathrm{Sq}(\mathrm{pred})=99.37 \%$

$\mathrm{R}-\mathrm{Sq}(\operatorname{adj})=99.60 \%$

$$
\begin{aligned}
\mathrm{SR} & =19.31+11.92 \times \mathrm{D}-300.88 \times \mathrm{F}-0.01 \times \mathrm{S}-7.43 \times \mathrm{D}^{2} \\
& +1755.23 \times \mathrm{F}^{2}-22.76 \times \mathrm{D} \times \mathrm{F}
\end{aligned}
$$

From response surface Eq. (3.2), the most significant factor on the surface roughness is feed. The next contribution on surface roughness is depth of cut and speed. The ANOVA for surface roughness is shown in table 3.4

Table 3.4: Analysis of Variance for SR

\begin{tabular}{|l|l|l|l|l|l|l|}
\hline $\begin{array}{l}\text { Sourc } \\
\text { e }\end{array}$ & $\begin{array}{l}\text { F } \\
\text { F }\end{array}$ & Seq SS & $\begin{array}{l}\text { Adj } \\
\text { SS }\end{array}$ & $\begin{array}{l}\text { Adj } \\
\text { MS }\end{array}$ & F & P \\
\hline $\begin{array}{l}\text { essio } \\
\text { n }\end{array}$ & 9 & 2400.34 & $\begin{array}{l}2400 . \\
34\end{array}$ & $\begin{array}{l}266.70 \\
5\end{array}$ & 721.39 & 0.000 \\
\hline $\begin{array}{l}\text { Linea } \\
\text { r }\end{array}$ & 3 & 2278.59 & 37.97 & 12.657 & 34.24 & 0.000 \\
\hline D & 1 & 5.70 & 3.31 & 3.308 & 8.95 & 0.008 \\
\hline F & 1 & 2272.03 & 31.69 & 31.695 & 85.73 & 0.000 \\
\hline S & 1 & 0.86 & 1.27 & 1.273 & 3.44 & 0.081 \\
\hline $\begin{array}{l}\text { Squar } \\
\text { e }\end{array}$ & 3 & 118.69 & $\begin{array}{l}118.6 \\
9\end{array}$ & 39.564 & 107.01 & 0.000 \\
\hline D $\times$ D & 1 & 2.68 & 2.68 & 2.680 & 7.25 & 0.015 \\
\hline
\end{tabular}

\begin{tabular}{|l|l|l|l|l|l|l|}
\hline $\mathrm{F} \times \mathrm{F}$ & 1 & 114.56 & $\begin{array}{l}114.5 \\
6\end{array}$ & $\begin{array}{l}114.56 \\
3\end{array}$ & 309.87 & 0.000 \\
\hline $\mathrm{S} \times \mathrm{S}$ & 1 & 1.45 & 1.45 & 1.450 & 3.92 & 0.064 \\
\hline $\begin{array}{l}\text { Intera } \\
\text { ction }\end{array}$ & 3 & 3.06 & 3.06 & 1.019 & 2.76 & 0.074 \\
\hline $\mathrm{D} \times \mathrm{F}$ & 1 & 1.40 & 1.40 & 1.400 & 3.79 & 0.068 \\
\hline $\mathrm{D} \times \mathrm{S}$ & 1 & 1.58 & 1.58 & 1.577 & 4.27 & 0.054 \\
\hline $\mathrm{F} \times \mathrm{S}$ & 1 & 0.08 & 0.08 & 0.080 & 0.22 & 0.647 \\
\hline $\begin{array}{l}\text { Resid } \\
\text { ual } \\
\text { Error }\end{array}$ & 17 & 6.29 & 6.29 & 0.370 & & \\
\hline Total & 26 & 2406.63 & & & & \\
\hline
\end{tabular}

RSM also generates the surface plots having influence of input variables on output along with the interactions of input variables on the selected output parameter.

\section{Surface Plot of T vs F, D}

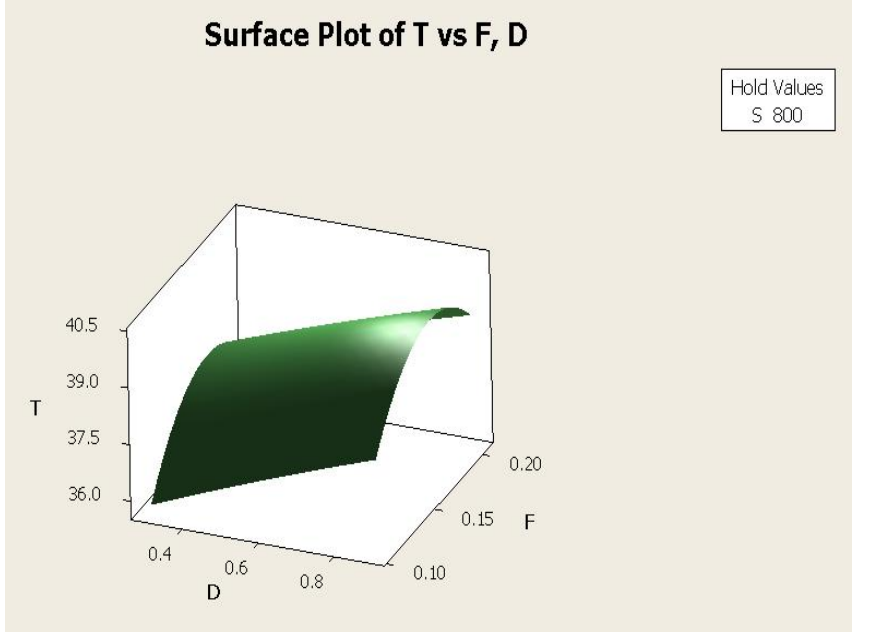

Fig. 3.1: Surface Plot of T vs F, D

\section{Surface Plot of T vs S, F}

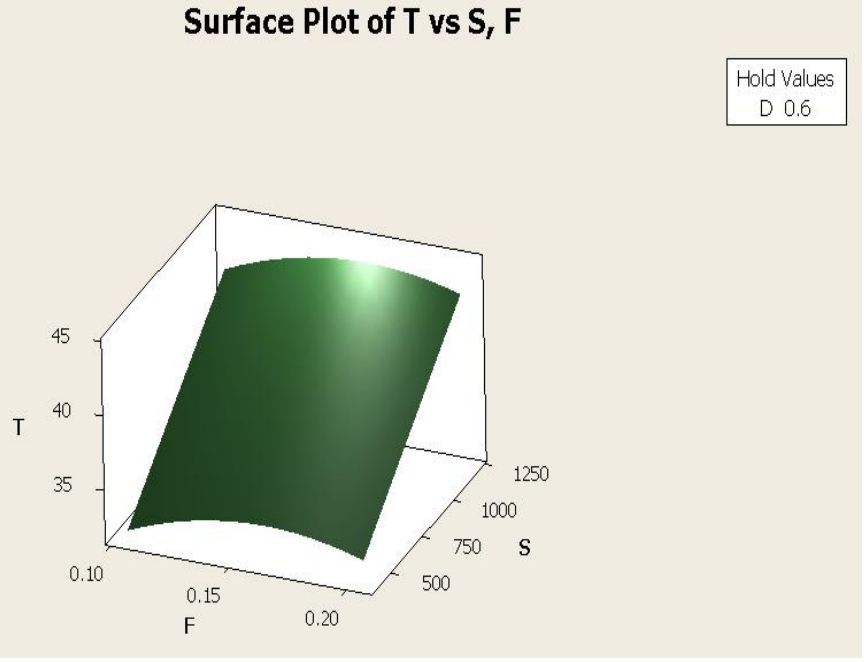

Fig. 3.2: Surface Plot of T vs S, F 


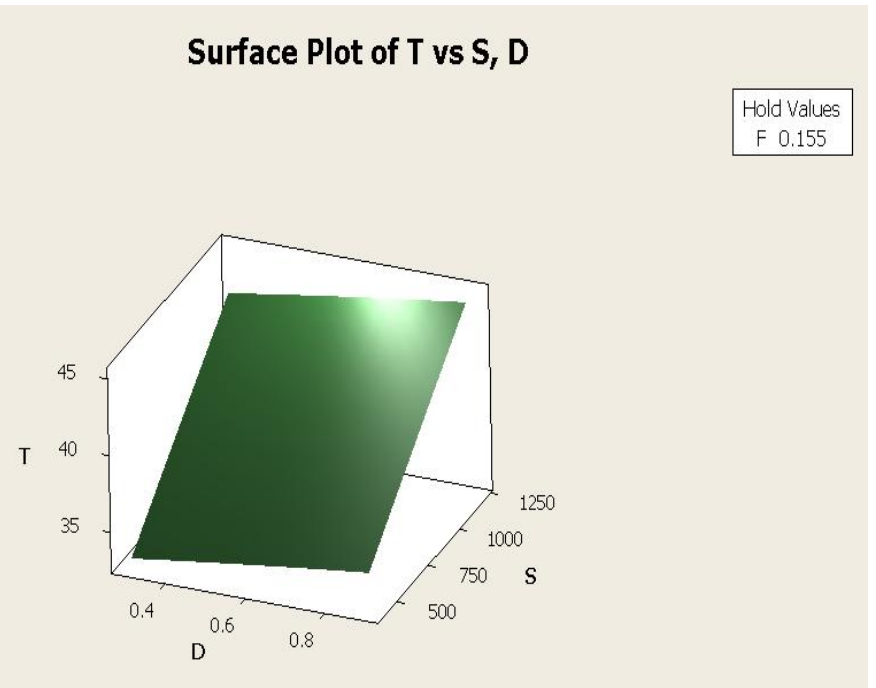

Fig. 3.3: Surface Plot of T vs S, D

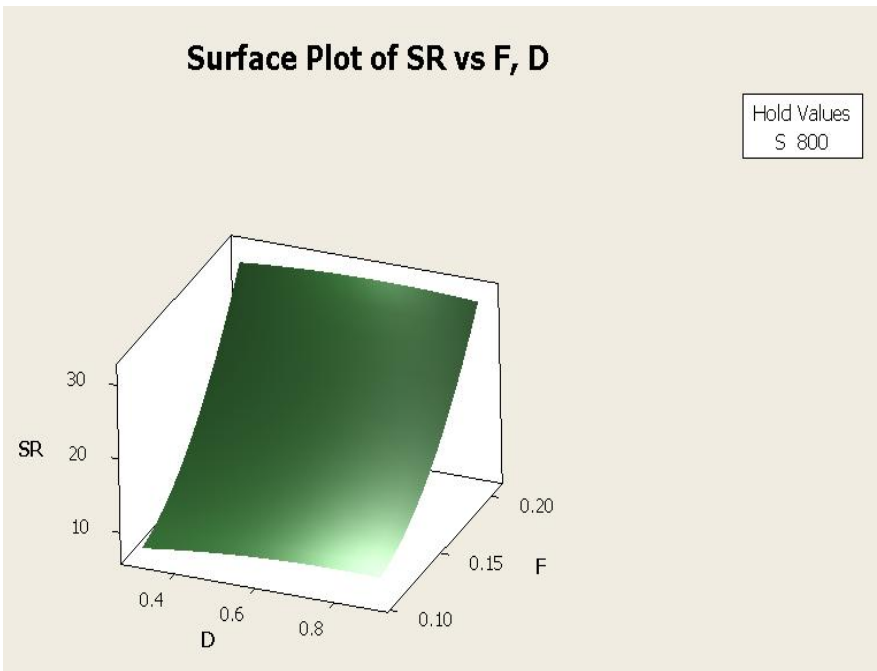

Fig. 3.4: Surface Plot of SR vs F, D

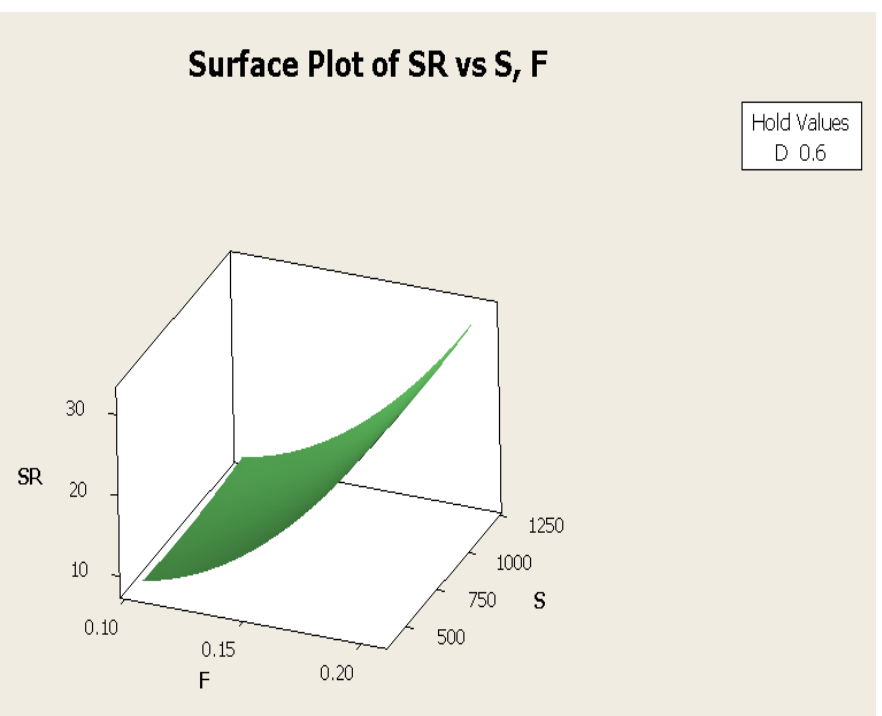

Fig. 3.5: Surface Plot of SR vs S, F

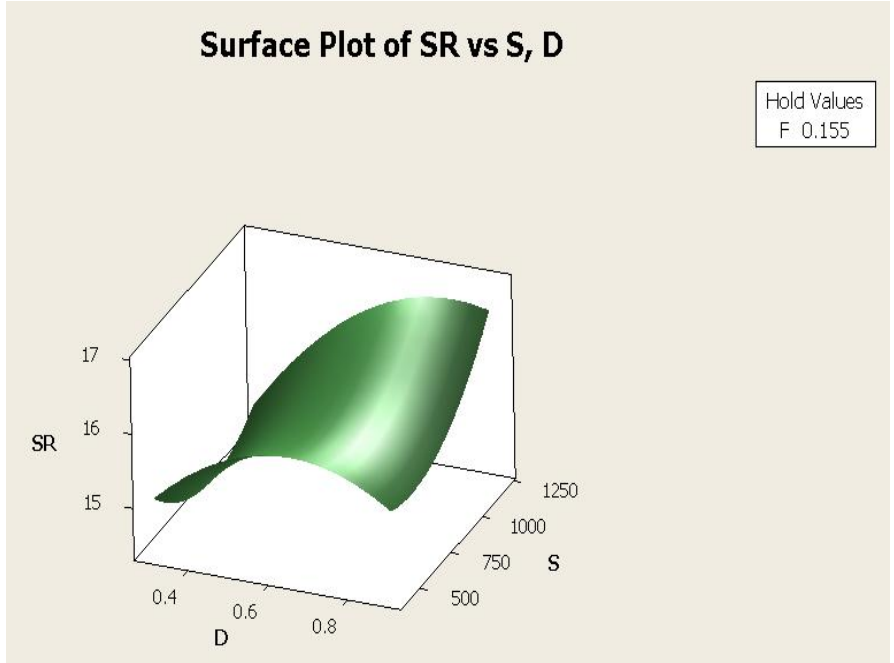

Fig. 3.6: Surface Plot of SR vs S, D

To understand how the response changes in a given direction by adjusting the design variables response surface graphs are used. Fig. 3.1, 3.2, \& 3.3 shows the surface plots of Temperature vs depth of cut $\&$ feed, feed $\&$ speed, depth of cut $\&$ speed. From these graphs it is observed that as the speed and depth of cut increases, the temperature increases. Fig. 3.4, $3.5 \& 3.6$ shows the surface plots of Surface Roughness vs depth of cut $\&$ feed, feed $\&$ speed, depth of cut $\&$ speed respectively. From these graphs it is observed that as the feed and speed increases, the surface roughness increases.

By using RSM the optimal values of temperature and surface roughness can be found. From fig. 3.7 the optimal values are

Dept of cut $\quad=0.3 \mathrm{~mm}$

Feed $\quad=0.105 \mathrm{~mm} / \mathrm{rev}$

Speed $\quad=400 \mathrm{rpm}$

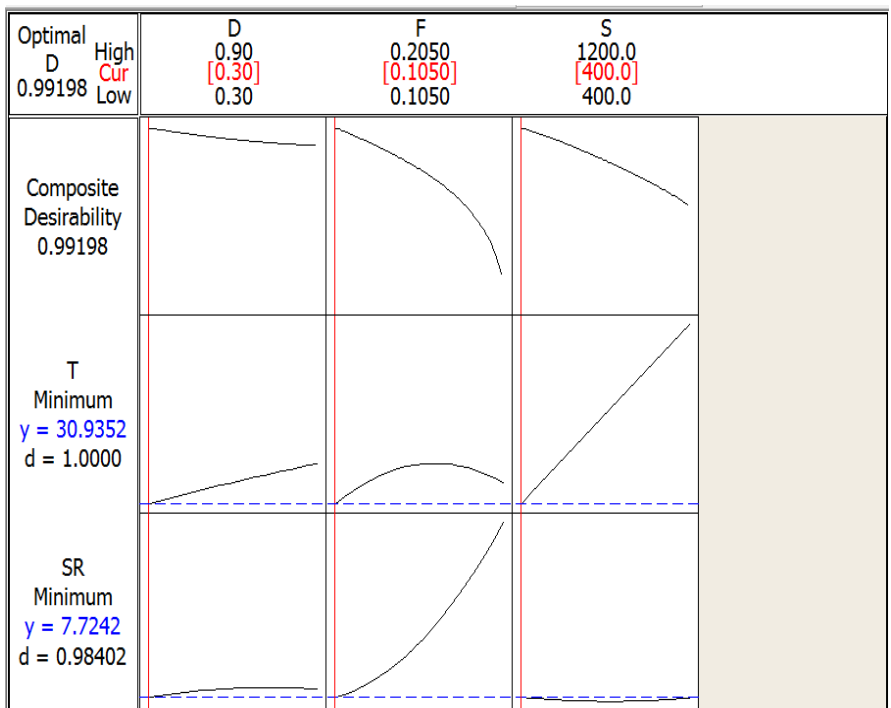

Fig. 3.7: Optimal Values. 


\section{CONCLUSION}

The current study was done to study the effect of machining parameters on the temperature and surface roughness. A mathematical equation has been generated between input parameters and response. The following conclusions are drawn from the study:

1. The temperature is mainly affected by depth of cut and cutting speed

2. The surface roughness is mainly affected by feed, depth of cut and speed.

The parameters taken in the experiments are optimized to obtain the minimum temperature and surface roughness. The optimum setting of cutting parameters are:

$\begin{array}{ll}\text { Dept of cut } & =0.3 \mathrm{~mm} \\ \text { Feed } & =0.105 \mathrm{~mm} / \mathrm{rev} \\ \text { Speed } & =400 \mathrm{rpm}\end{array}$

\section{FUTURE SCOPE}

The turning process is performed in dry condition. The experiment may be conducted in future by measuring tool wear and material removal rate. The optimal cutting parameters for minimum tool wear and minimum surface roughness and maximum material removal rate can be found out.

\section{REFERENCES}

[1] N.V.S.S. Sagar, M. Murali Mohan, Optimization of machining parameters of En36 material using Taguchi method, NAFEMS India Regional Conference 2015, Procedia (2015) - 36.

[2] J. Paro, H. Hänninen, V. Kauppinen, Tool wear and machinability of HIPed P/M and conventional cast duplex stainless steels, Wear. 249(3-4) (2001) 279284.

[3] I. Korkut, M. Kasap, I. Çiftci, U. Seker, Determination of optimum cutting parameters during machining of AISI 304 austenitic stainless steel, Materials and Design 25 (2004) 303-305.

[4] B. Latha, V.S. Senthilkumar, Modeling and analysis of surface roughness parameters in drilling GFRP composites using fuzzy logic, Materials and Manufacturing Processes 25 (8) (2010) 817-827.

[5] Kamal Hassan, Anish Kumar, M.P.Garg, Experimental investigation of Material removal rate in CNC turning using Taguchi method, International Journal of Engineering Research and Applications (IJERA) 2,2012, 1581-1590.

[6] Routara , BC ; Sahoo, P ; Bandyopadhyay, A Multi objective optimization of cutting parameters for surface roughness in CNC turning using RSM s Volume 2, 15 December, 2008.

[7] Lalwani, DI ; Mehta, NK ; Jain , PK, Effect of cutting conditions on forces in finish hard turning of MDN300 steel Volume 2, 15 December, 2008. $\left(23^{\text {rd }}\right.$ AIMTDR)

[8] The parametric effect and optimization on JIS S45 steel turning Hasnul Hadi1, Liyana Tajul2, Z.A.
Zailani3, M.F.M.A Hamzas4, M.S Hussin Faculty of Manufacturing Engineering, Universiti Malaysia Perlis (UniMAP) 02600 Arau, Perlis, Malaysia.

[9] Selection of process parameters of honing of cylinder liners using design of experts approach.[Kanthababu, M; Shunmugam, MS; Singaperumal, M;] Volume 1, 15 December, 2008.

[10] International Journal of Production Technology and Management (IJPTM) Volume 3, Issue 1, JanuaryDecember (2012), pp. 09-15 A parametric analysis and optimization of tool life in dry turning of en 24 steel using Taguchi method.

[11] Yigit et al. (2011), "Multi-Objective Optimization of the Cutting Forces in Turning Operations Using the Grey-Based Taguchi Method" ISSN 1580-2949.

[12] Kamal, Anish and M.P.Garg (2012), "Experimental investigation of Material removal rate in $\mathrm{CNC}$ turning using Taguchi method'International Journal of Engineering Research and Applications (IJERA) Vol. 2, Issue 2,Mar-Apr 2012, pp.1581-1590

[13] Dhavamani and Alwarsamy, "Optimization of Cutting Parameters of Composite Materials using Genetic Algorithm" European Journal of Scientific Research ISSN 1450-216X Vol.63 No.2 (2011), pp.279-285.oct-2011

[14] Sijo M.T and Biju.N (2010), "Taguchi Method for Optimization of Cutting Parameters in Turning Operations" Proc. of. Int. Conf.on Advances in Mechanical Engineering 2010.

[15] Rama and Padmanabhan. G (2012), "Application of Taguchi methods and ANOVA in optimization of process parameters for metal removal rate in electrochemical machining of $\mathrm{Al} / 5 \% \mathrm{SiC}$ composites" International Journal of Engineering Research and Applications (IJERA) Vol. 2, Issue 3, May-Jun 2012, pp. 192-197

[16] Ballal, Inamdar and Patil P.V. (2012), "Application Of Taguchi Method For Design Of Experiments In Turning Gray Cast Iron" International Journal of Engineering Research and Applications (IJERA) Vol. 2, Issue 3, May-Jun 2012, pp.1391-1397 36

[17] Ashish Yadav, Ajay Bangar, Rajan Sharma, Deepak Pal ," Optimization of Turning Process Parameters for Their Effect on EN8 Material Work piece Hardness by Using Taguchi Parametric Optimization Method," International Journal of Mechanical and Industrial Engineering (IJMIE), ISSN No. 2231 6477, Volume-1, Issue-3, 2012.

[18] Puneet mangla, Nishant kr. Singh, Yashvir singh (2011) "Study of effect of turning parameters on work piece hadness using Taguchi method". ICAM, pp- 695-700.

\section{BIOGRAPHIES}

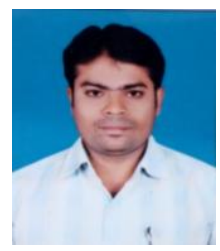

M. Murali Mohan, Asst. Professor, Dept. of Mechanical Engineering, G. Pulla Reddy Engineering College, Kurnool 518007. A.P., India. e-mail: muralikam22@gmail.com 


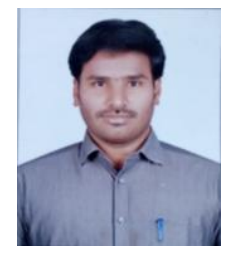

N.V.S.S. Sagar, Asst. Professor, Dept. of Mechanical Engineering, G. Pulla Reddy Engineering College, Kurnool - 518007. A.P., India.

e-mail: nvsssagar@gmail.com

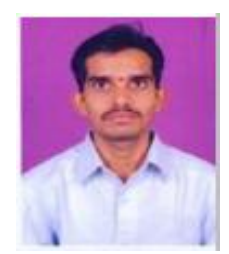

M. Lava Kumar, Asst. Professor, Dept. of Mechanical Engineering, G. Pulla Reddy Engineering College, Kurnool - 518007. A.P., India.

e-mail: lavakumarm@rediffmail.com

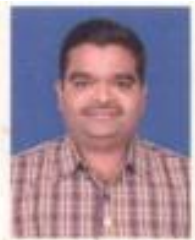

Dr. E. Venugopal Goud, Asso. Professor, Dept. of Mechanical Engineering, G. Pulla Reddy Engineering College, Kurnool 518007. A.P., India.

e-mail: goudvenu@gmail.com 